\title{
Detection of Ectoparasite Lernaea cyprinacea (Copepoda: Lernaeidae) on some Cypriniformes Fish from the Mediterranean Region of Turkey
}

\author{
Deniz INNAL
}

Burdur Mehmet Akif Ersoy University, Department of Biology, Burdur, Turkey ORCID ID: Deniz INNAL: https:/ / orcid.org/0000-0002-1686-0959

\begin{abstract}
Received: 17.07.2020
Accepted: 28.10 .2020

Published online: 05.11 .2020

Issue published: 31.12 .2020

Abstract: Lernaea cyprinacea L.,1758 is a lernaeid copepod species usually known as anchor worm. It is usually reported as having a wide range of host susceptibility. Parasites belonging to the genus Lernaea can have serious deleterious effects on their freshwater fish hosts. Parasites belonging to the genus Lernaea, it has been reported from several host fish species to date in Turkey. Mediterranean region of Turkey supports a rich diversity of Cypriniformes fish fauna, with a high percentage of endemic species. This study reports the infection of $L$. cyprinacea on some native and alien Cypriniformes fish in the Mediterranean region of Turkey. Barbus xanthos, Alburnus baliki, Pseudophoxinus zekayi and Pseudorasbora parva were found as new host records for L. cyprinacea.
\end{abstract}

Keywords: Endemism, non-indigenous species, ectoparasite, freshwater.

\section{Türkiye'nin Akdeniz Bölgesi'nden Bazı Cypriniformes Balıklarında Ektoparazit Lernaea cyprinacea' nin (Copepoda: Lernaeidae) Tespit Edilmesi}

Öz: Lernaea cyprinacea L., 1758, çapa kurdu olarak bilinen bir lernaeid kopepod türüdür. Genellikle geniş bir konakçı duyarlılığına sahip olduğu bildirilmektedir. Lernaea cinsine ait parazitlerin tatlı su balıkları konakçıları üzerinde ciddi zararlı etkileri bulunmaktadır. Larnea cinsine ait parazitler, Türkiye'de bugüne kadar birçok konak balık türünden bildirilmiştir. Türkiye'nin Akdeniz bölgesi, yüksek endemik tür yüzdesi ile zengin bir Cypriniformes balık faunası çeşitliliğini barındırmaktadır. Bu çalışma, Türkiye'nin Akdeniz bölgesindeki bazı yerli ve yabancı Cypriniformes balıklarında L. cyprinacea enfeksiyonunu açılamaktadır. Barbus xanthos, Alburnus baliki, Pseudophoxinus zekayi ve Pseudorasbora parva, L. cyprinacea için yeni konak kayıtları olarak bulunmuştur.

Anahtar kelimeler: Endemizm, yabancı türler, ektoparazit, tatlısu.

\section{Introduction}

The order Cypriniformes is the most diverse order of freshwater fish. In the inland waters of Turkey, this order is represented by 278 species according to Çiçek, Sungur, and Fricke (2020). Ecology of parasites of the order Cypriniformes has been the center of an increasing attention for two decades (Dorovskikh \& Stepanov, 2009; Soylu, Uzmanoğlu, Çolak, \& Soylu, 2017; Gabagambi \& Skorping, 2018; Czerniejewski, Rybczyk, Linowska, \& Sobecka, 2019).

Copepod parasites have recently been highlighted as serious pathogenic problems in order Cypriniformes (Unal et al., 2017). Among the Copepod parasites, L. cyprinacea was mostly described from the gills, skin or fins of wild and cultured Cypriniformes fish (Boane, Cruz, \& Saraiva 2008; Novakov et al., 2015; Demir \& Karakisi, 2016; Soylu et al., 2017).

There have been numerous reports of L. cyprinacea from Turkey and adjacent regions: Iraq (Mhaisen, 1982), Iran (Barzegar, Raeisi, Bozorgnia, \& Jalali, 2008; Raissy \& Ansari, 2012; Raissy, Sohrabi, Rashedi, \& Ansari, 2013; Daghigh Roohi, Sattari, Nezamabadi, \& Ghorbanpour, 2014) as well as Mediterranean countries (Nofal, Zaki, \& El-Shebly, 2016; Ahnelt et al., 2018).

After the first report of L. cyprinacea in Turkey, several studies have demonstrated that the parasite is widespread in this country and identified as a possible threat to the endemic and economic fish stocks. $L$. cyprinacea has been found infesting Cypriniformes host species in Turkey, as follows, Carassius carassius in Kovada Lake (Geldiay \& Balık, 1974); Cyprinus carpio (Burgu, Oguz, Korting, \& Guralp, 1988), Chondrostoma nasus in Tahtalı Dam Lake, Izmir (Demir, 2008); Cyprinus carpio in Tahtalı Dam Lake, Izmir (Karakisi \& Demir, 2012); Carasius gibelio in Karacaören II Dam Lake, Burdur (Kır \& Samanc1, 2012); Tinca tinca in Seyhan Dam Lake, Adana (Ince, 2013); Cyprinion macrostomus in Murat River, Bingöl (Koyun, Ulupinar, \& Mart, 2015); Pseudophoxinus burduricus and Oxynoemacheilus anatolicus in Düğer Creek, Burdur (Innal et al., 2017); Pseudophoxinus egridiri in Eğirdir Lake, Isparta (Akcimen et al., 2018); Chondrostoma beysehirense and Squalius cephalus from the Üzümlü pond, Konya (Erbatur, Yağc1, Öktener, \& Akcimen, 2018).

Mediterranean region of Turkey supports a rich diversity of Cypriniformes fish fauna with a high percentage of endemic species. Although a large number of endoparasite species has been reported in this order, studies on ectoparasite species are very limited. The present study was conducted to identify the parasitic infections of L. cyprinacea on some native and alien Cypriniformes species in the Mediterranean region of Turkey. 


\section{Material and Methods}

Overall, 679 individuals belonging to seven fish species (Table 1) were analyzed: Pseudophoxinus burduricus Küçük, Gülle, Güçlü, Çiftçi, \& Erdoğan, 2013 (Burdur spring minnow); Pseudophoxinus zekayi Bogutskaya, Küçük \& Atalay, 2006 (Ceyhan spring minnow); Barbus xanthos (Güçlü, Kalaycı, Küçük, Turan 2020); Tinca tinca (Linnaeus, 1758) (Tench); Pseudorasbora parva (Temminck \& Schlegel, 1846) (Stone moroko); Carassius gibelio (Bloch, 1782) (Prussian carp); Alburnus baliki Bogutskaya, Küçük \& Ünlü, 2000 (Antalya bleak).

The investigation was carried out from May 2013 to July 2020. Fish were collected using beach seine nets, longline nets, and electroshock methods in ten aquatic systems (Fig. 1) (on the map; 1: Lake Gölhisar; 2: Dalaman River; 3: Değirmendere Creek; 4: Lake Karataş; 5: Soğanlı Pond; 6: Çanaklı Pond; 7: Onaç Reservoir; 8: Lake Beyşehir; 9: Karpuzçay Creek; 10: Ceyhan River).

Fish were transported immediately to the Burdur Mehmet Akif Ersoy University Ichthyology Laboratory in plastic bags. Each fish was measured (total length in $\mathrm{cm}$ ) and weighed $(\mathrm{g})$ before observation. Fish species were examined for the presence of L. cyprinacea. Areas around the fins, nostril, opercular cavity, and skin were examined with a dissecting microscope. L. cyprinacea was identified using a dissecting microscope and according to Bauer (1987). Prevalence and intensity of infection were recorded (Bush, Lafferty, Lotz, \& Shostak, 1997).

Table 1. Systematic overview of host fish species

\begin{tabular}{clllc}
\hline No & Host & Common name & Order & Family \\
\hline $\mathbf{1}$ & Pseudophoxinus burduricus & Burdur spring minnow & Cypriniformes & Leuciscidae \\
$\mathbf{2}$ & Alburnus baliki & Antalya bleak & Cypriniformes & Leuciscidae \\
$\mathbf{3}$ & Pseudophoxinus zekayi & Ceyhan spring minnow & Cypriniformes & Leuciscidae \\
$\mathbf{4}$ & Barbus xanthos & Eşen barbel & Cypriniformes & Cyprinidae \\
$\mathbf{5}$ & Tinca tinca & Tench & Cypriniformes & Tincidae \\
$\mathbf{6}$ & Pseudorasbora parva & Stone moroko & Cypriniformes & Gobionidae \\
$\mathbf{7}$ & Carassius gibelio & Prussian carp & Cypriniformes & Cyprinidae \\
\hline
\end{tabular}

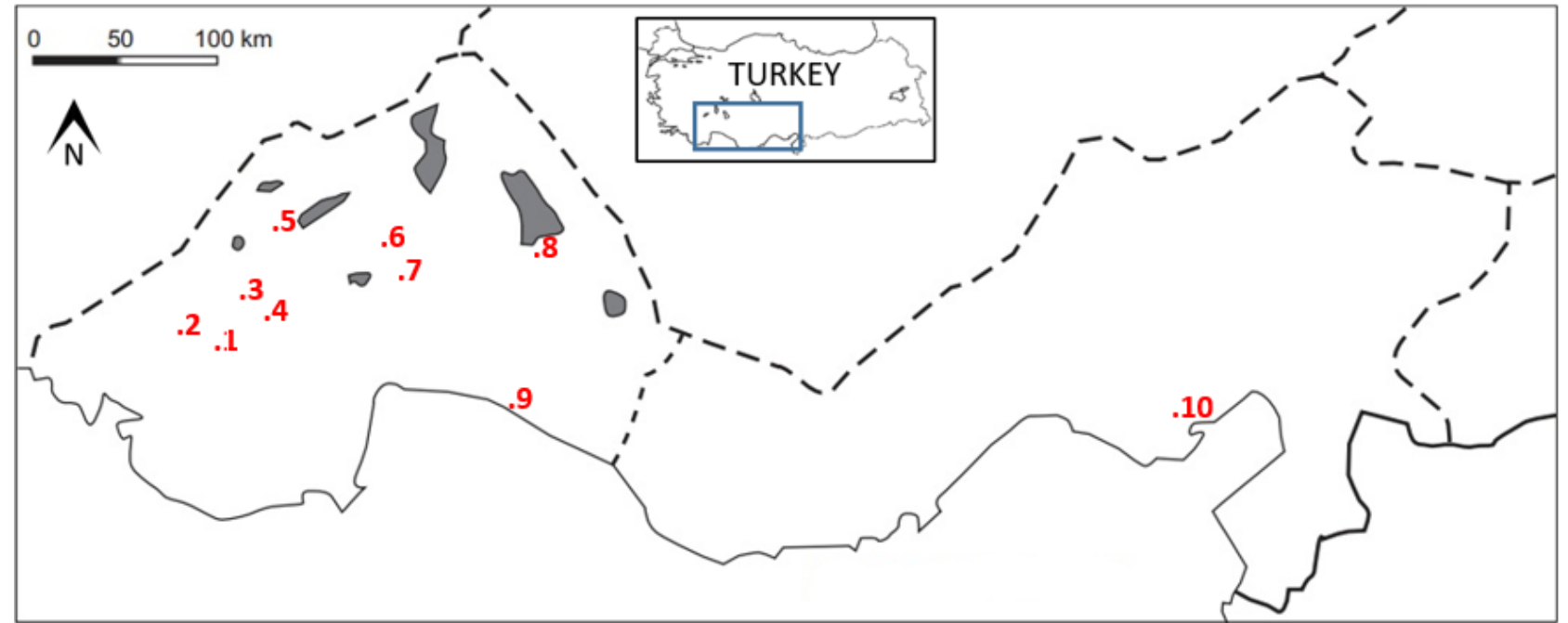

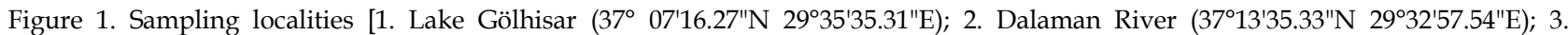

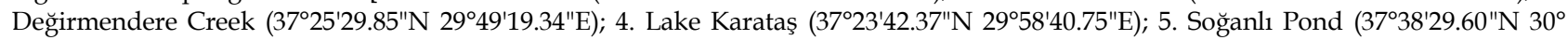

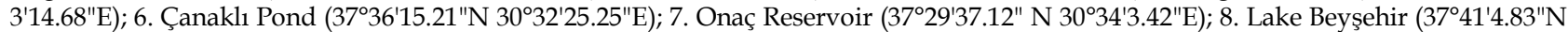

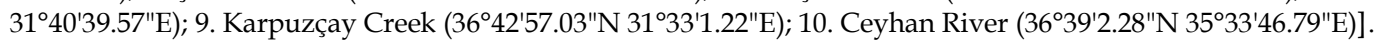

\section{Results}

Among the seven species examined for infestation with $L$. cyprinacea, the highest prevalence of infection was reached in Pseudophoxinus burduricus, a native fish from Değirmen Creek, followed by Çanaklı Pond population of C. gibelio and Onaç Reservoir population of C. gibelio $(48 \% ; 15.38 \%$; $11.02 \%$, respectively) (Fig. 2). With respect to mean intensity, the highest values were recorded in Gölhisar Lake population of Tinca tinca, Beyşehir Lake population of Carassius gibelio, Karataş Lake Population of Carassius gibelio (3.7; 3.5; 3 parasites/fish, respectively).

\section{Discussion}

Lernaea is a copepod, which is parasitic on many species of freshwater fish and is extremely common among the Cypriniformes fish. In Turkey, previous records of the genus Lernaea on order Cypriniformes are provided by Geldiay and Balık (1974); Burgu et al. (1988); Demir (2008); Karakisi and Demir (2012); Kir and Samanc1 (2012); Ince (2013); Koyun et al. (2015); Innal et al. (2017); Akcimen et al. (2018); Erbatur et al. (2018). To date, 11 Cypriniformes species have been reported as host of L. cyprinacea in Turkey. This study documents the expanded geographical and host distribution of L. cyprinacea in Turkey. The present findings of L. cyprinacea from Barbus xanthos, Alburnus baliki, Pseudophoxinus zekayi, and Pseudorasbora parva represent the first records of the copepod from these fish in Turkey. This copepod is characterized with a wide host and geographic distribution and adapted to a large variety of habitat in Turkey.

In this study, Lernaea parasites were collected from the skin, gills, opercular cavity, and fins of Pseudophoxinus 
burduricus, Pseudophoxinus zekayi, Barbus xanthos, Tinca tinca, Pseudorasbora parva, Carassius gibelio and Alburnus baliki in different water bodies. The highest infection prevalence value was found in Pseudophoxinus burduricus from Değirmendere Creek (48\%) and the lowest in Carassius gibelio from Beyşehir Lake (3\%). The mean intensity varied from 1 parasite in Alburnus baliki in Karpuzçay Creek and Carassius gibelio in Soğanlı Reservoir to 3.7 in Tinca tinca from Gölhisar Lake.

Different prevalence and intensity values in $L$. cyprinacea infections between the localities and hosts may depend on the changing habitat conditions such as temperature, $\mathrm{pH}$, salinity and dissolved oxygen, and biotic parameters. For some populations, the data of infections were not representative for four seasons. In addition to seasonality and habitat conditions, the observed difference in infection parameters could be due to the sample size, sampling differences, feeding habits of fish species, sex ratio, length range, and host resistance.

A number of studies have investigated the differences in parasitism levels of L. cyprinacea on host Cypriniformes species (Gutiérrez-Galindo \& LacasaMillán, 2005; Barson et al., 2008; Pérez-Bote, 2010; Stavrescu-Bedivan, Popa, Aioanei, \& Popa, 2011). In some cases, they can be very abundant: in Chondrostoma orientale
Bianco \& Banarescu, 1982 from the Kor River Basin, southwestern Iran the prevalence of L. cyprinacea infections reached $100 \%$, with a mean intensity of 10,3 parasites per fish (Sayyadzadeh \& Roudbar, 2015), and in Hypophthalmichthys molitrix from Manzala area $64 \%$ of the specimens were infected (Nofal et al., 2016).

In this study, it was determined that L. cyprinacea affected native and introduced Cypriniformes fish in Turkey. The results of this study encourage further investigations in different aquatic systems of the Mediterranean region of Turkey in order to identify prevalence and intensity of L. cyprinacea infestation for other Cypriniformes fish species. Moreover, the differences in morphological structure of the parasite individuals (L. cyprinacea) between regions and hosts should be investigated by molecular genetic methods.

Acknowledgements: The author would like to thank Prof. Dr. Iskender Gülle who helped the field studies in some regions. Field studies in Ceyhan river was financially supported by Scientific and Technological Research Council of Turkey (Tübitak) under the Project numbered KBAG, 114 Z 259.

Conflict of interest: The author declares that there is no conflict of interest.

\section{Prevalence \%}

\section{Pseudophoxinus burduricus (Degirmendere) Pseudophoxinus zekayi (Ceyhan) Carassius gibelio (Çanaklı) Carassius gibelio (Onaç) Carassius gibelio (Karataş) Tinca tinca (Gölhisar) Carassius gibelio (Soğanlı) Barbus xanthos(Dalaman) Pseudorasbora parva (Onaç) Alburnus baliki (Karpuzçay) Carassius gibelio (Beyşehir)}

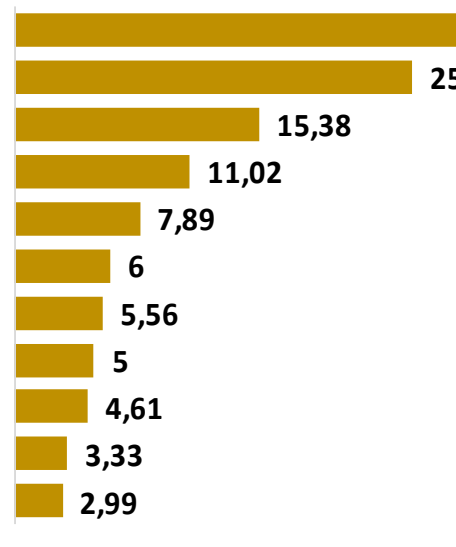

0 10 20 30 40 50 60

\section{Intensity}

\author{
Tinca tinca (Gölhisar) \\ Carassius gibelio (Beyşehir) \\ Carassius gibelio (Karataş) \\ Pseudorasbora parva (Onaç) \\ Pseudophoxinus zekayi (Ceyhan) \\ Carassius gibelio (Soğanlı) \\ Barbus xanthos(Dalaman) \\ Carassius gibelio (Onaç) \\ Pseudophoxinus burduricus (Degirmendere) \\ Carassius gibelio (Çanaklı) \\ Alburnus baliki (Karpuzçay)
}

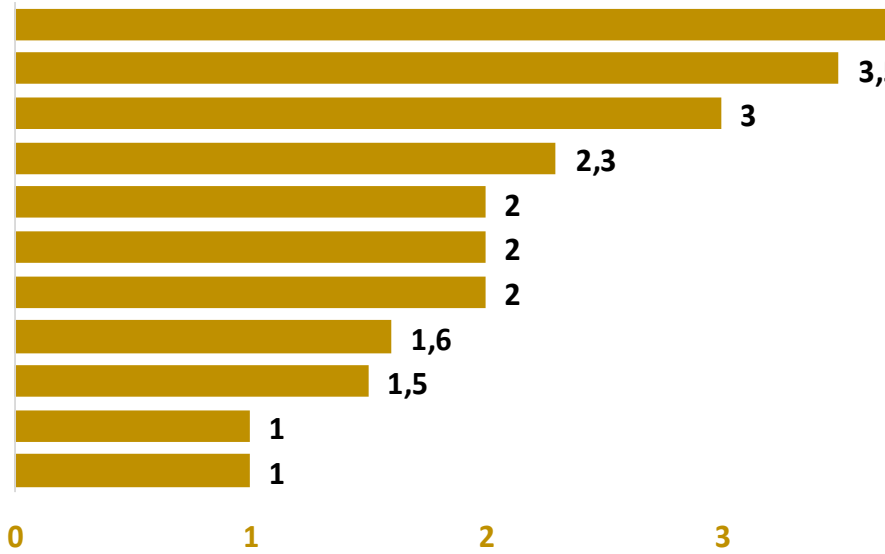


Table 2. Occurence of Lernaea cyprinacea infestation in host fish species ( $N=$ total number of hosts examined; $\mathrm{N}^{\prime}=$ number of infected fishes)

\begin{tabular}{|c|c|c|c|c|c|c|c|}
\hline No & Host & Location & Status & $\mathbf{N}$ & $\mathbf{N}^{\prime}$ & $\begin{array}{l}\text { Total length (cm) } \\
\text { Range (Min-Max) }\end{array}$ & $\begin{array}{l}\text { Weight (g) } \\
\text { Range (Min-Max) }\end{array}$ \\
\hline 1 & Pseudophoxinus burduricus & Degirmendere Creek & Endemic & 25 & 12 & $4.9-10.7$ & $1.4-16$ \\
\hline 2 & Alburnus baliki & Karpuzçay Creek & Endemic & 60 & 2 & $4.2-10.8$ & $0.6-15.7$ \\
\hline 3 & Pseudophoxinus zekayi & Ceyhan River & Endemic & 4 & 1 & $9.5-12.8$ & $9.1-30.4$ \\
\hline 4 & Barbus xanthos & Dalaman Stream & Native & 60 & 3 & $3.5-20$ & $0.5-80$ \\
\hline 5 & Tinca tinca & Gölhisar Lake & Alien & 50 & 3 & $16.2-39.3$ & $78.5-1056$ \\
\hline 6 & Pseudorasbora parva & Onaç Reservoir & Alien & 217 & 10 & $2.8-6.7$ & $0.143-2.9$ \\
\hline 7 & Carassius gibelio & Onaç Reservoir & Alien & 127 & 14 & $3.4-27.9$ & $0.5-470.4$ \\
\hline 8 & Carassius gibelio & Çanaklı Reservoir & Alien & 13 & 2 & $4.4-12.6$ & $1.2-35.7$ \\
\hline 9 & Carassius gibelio & Soğanlı Reservoir & Alien & 18 & 1 & $8.4-14.1$ & $10.1-48$ \\
\hline 10 & Carassius gibelio & Karataş Lake & Alien & 38 & 3 & $20-33$ & $153-560$ \\
\hline 11 & Carassius gibelio & Beyşehir Lake & Alien & 67 & 2 & $18.1-24.2$ & $86-263$ \\
\hline
\end{tabular}

Ethics committee approval: This study was performed in accordance with ethical standards of animal experiments. Legal research ethics committee approval permissions for the study were obtained from the Burdur Mehmet Akif Ersoy University, Animal Experiments Local Ethics Committee (No: 659)

\section{References}

Ahnelt, H., Konecny, R., Gabriel, A., Bauer, A., Pompei, L., Lorenzoni, M., \& Sattmann, H. (2018). First report of the parasitic copepod Lernaea cyprinacea (Copepoda: Lernaeidae) on gobioid fishes (Teleostei: Gobionellidae) in southern Europe. Knowledge and management of aquatic ecosystems, (419) 34, 1-6.

Akcimen, U., Apaydın Yağcl, M., Yeğen, V., Uysal, R., Bilgin, F., \& Yağcl, A. (2018). First Report of Eustrongylides excisus Larvae and Lernaea cyprinacea on Eğirdir Minnow (Pseudophoxinus egridiri) 13th International Symposium on Fisheries and Aquatic Sciences Proceedings Book ISBN: 978-605-68894-0-0 Publication of e-book date: 17.12.2018

Barson, M., Mulonga, A., \& Nhiwatiwa, T. (2008). Investigation of a parasitic outbreak of Lernaea cyprinacea Linnaeus (Crustacea: Copepoda) in fish from Zimbabwe. African Zoology, 43(2), 175-183.

Barzegar, M., Raeisi, M., Bozorgnia, A., \& Jalali, B. (2008). Parasites of the eyes of fresh and brackish water fishes in Iran. Iranian Journal of Veterinary Research, 9(3), 256-261.

Bauer, O.N. (1987). Guide for identification of parasites of the freshwater Fish Fauna of the USSR, Vol 3. Zoological Institute, Academy of Sciences of the USSR, Leningrad.

Boane, C., Cruz, C., \& Saraiva, A. (2008). Metazoan parasites of Cyprinus carpio L. (Cyprinidae) from Mozambique. Aquaculture, 284(1-4), 59-61.

Burgu, A., Oguz, T., Korting, W., \& Guralp, N. (1988). Parasites of freshwater fishes in some areas of Central Anatolia. Journal of Etlik Veterinary Microbiology, 6, 143-165.

Bush, A.O., Lafferty, K.D., Lotz, J.M., \& Shostak, A.W. (1997). Parasitology meets ecology on its own terms: Margolis et al, Revisited. Journal of Parasitology, 83(4), 575-583.

Czerniejewski, P., Rybczyk, A., Linowska, A., \& Sobecka, E. (2019). New location, food composition, and parasitic fauna of the invasive fish Pseudorasbora parva (Temminck \& Schlegel, 1846) (Cyprinidae) in Poland. Turkish Journal of Zoology, 43(1), 94-105.

Çiçek, E., Sungur, S., \& Fricke, R. (2020). Freshwater lampreys and fishes of Turkey; a revised and updated annotated checklist 2020. Zootaxa, 4809(2), 241-270.

Daghigh Roohi, J., Sattari, M., Nezamabadi, H., \& Ghorbanpour, N. (2014). Occurrence and intensity of parasites in Prussian carp, Carassius gibelio from Anzali wetland, Southwest Caspian Sea. Iranian Journal of Fisheries Sciences, 13(2), 276-288.

Demir, S. (2008). Metazoan parasites of nase (Chondrostoma nasus L., 1758) inhabiting in Tahtalı Dam Lake (İzmir), (MsC thesis). Ege University, İzmir, Turkey.

Demir, S., \& Karakisi, H. (2016). Metazoan Parasite Fauna of the Prussian carp, Carassius gibelio (Bloch, 1782) (Cyprinidae), from Marmara Lake, Turkey. Acta Zoologica Bulgarica, 68(2), 265-268.

Dorovskikh, G.N., \& Stepanov, V.G. (2009). Structure of component parasite communities in the grayling, Thymallus thymallus L. (Salmoniformes, Thymallidae), and minnow, Phoxinus phoxinus L. (Cypriniformes, Cyprinidae), from the upper reaches of the Pechora River. Biology Bulletin, 36(3), 298-306.

Erbatur, I., Yağcl, A., Öktener, A., \& Akcimen, U. (2018). New Locality for Lernaea cyprinacea (Copepoda; Lernaeidae) in Turkey 13th International Symposium on Fisheries and Aquatic Sciences Proceedıngs Book ISBN: 978-605-68894-0-0 Publication of e-book date: 17.12.2018.
Gabagambi, N.P., \& Skorping, A. (2018). Spatial and temporal distribution of Ligula intestinalis (Cestoda: Diphyllobothriidea) in usipa (Engraulicypris sardella) (Pisces: Cyprinidae) in Lake Nyasa. Journal of Helminthology, 92(4), 410-416.

Geldiay, R., \& Balık, S. (1974). Ecto and Endoparasites found the freshwater fish of Turkey. Ege University Science Faculty Monographies, 14.

Gutiérrez-Galindo, J.F., \& Lacasa-Millán, M.I. (2005). Population dynamics of Lernaea cyprinacea (Crustacea: Copepoda) on four cyprinid species. Diseases of Aquatic Organisms, 67(1-2), 111-114.

Ince, H. (2013). Adana ili Seyhan Baraj Gölünde Yetiştiriciliği ve Avcılığı Yapılan iç su Balıklarındaki Parazitlerin Tespiti, Selçuk Üniversitesi, Sağlık Bilimleri Enstitüsü (Yüksek Lisans tezi), Konya, Türkiye.

Innal, D., Avenant Oldewage, A., Dogangil, B., Stavrescu Bedivan, M.M., Ozmen, O., \& Mavruk, S., (2017). Susceptibility of endemic and nonindigenous fish to Lernaea cyprinacea (Copepoda: Lernaeidae): a case study from Düger Spring, Turkey. Bulletin of The European Association of Fish Pathologists, 37(3), 100-109.

Karakisi, H., \& Demir, S. (2012). Metazoan parasites of the common carp (Cyprinus carpio L., 1758) from Tahtali Dam Lake (Izmir). Türkiye Parazitoloji Dergisi, 36(3), 174-177.

Kır, I., \& Samanc1, I. (2012). The Parasite Fauna of Crucian Carp (Carassius gibelio Bloch., 1782) Inhabiting Karacaören II Dam Lake (Burdur, Isparta). SDÜ Ĕ̆irdir Su Ürünleri Fakültesi Dergisi, 8(2), 38-42.

Koyun, M., Ulupinar, M., \& Mart, A. (2015). First record of Lernaea cyprinacea L 1758 (Copepoda: Cyclopoidea) on Cyprinion macrostomus Heckel, 1843 from eastern Anatolia, Turkey. Biharean Biologist, 9, 44-46.

Mhaisen, F.T. (1982). The anchor worm, Lernaea cyprinacea, in Basrah University Fish Farm. Mesopotamian Journal of Marine Science, 1, 3-11.

Nofal, M.E., Zaki, V.H., \& El-Shebly, A.A. (2016). Implications of heavy infestation of Lernaea cyprinacea (Crustacea: Copepoda) of Silver carp, Hypophthalmichthys molitrix at Manzala area, with trial for control using Trichlorfon. International Journal of Fisheries and Aquatic Studies, 4(6), 314318.

Novakov, N., Ćirković, M., Kartalović, B., Pelić, M., Matić, D., Ljubojević, D., \& Božić, B. (2015). Infestation of Lernaea cyprinacea (Crustacea: Cepopoda) in different categories of common carp (Cyprinus carpio) reared in Serbia. Arhiv Veterinarske Medicine/Archives of Veterinary Medicine, 8(2), 11-18.

Pérez-Bote, J.L. (2010). Barbus comizo infestation by Lernaea cyprinacea (Crustacea: Copepoda) in the Guadiana River, southwestern Spain. Journal of Applied Ichthyology, 26(4), 592-595.

Raissy, M., \& Ansari, M. (2012). Parasites of some freshwater fish from Armand river, chaharmahal va Bakhtyari province, Iran. Iranian Journal of Parasitology, 7(1), 73-79.

Raissy, M., Sohrabi, H.R., Rashedi, M., \& Ansari, M. (2013). Investigation of a parasitic outbreak of Lernaea cyprinacea Linnaeus (Crustacea: Copepoda) in Cyprinid fish from Choghakhor lagoon. Iranian Journal of Fisheries Sciences, 12(3), 680-688.

Sayyadzadeh, G., \& Roudbar, A.J. (2015). Occurrence of Lernaea cyprinacea (Crustacea: Copepoda) in an endemic cyprinid fish, Chondrostoma orientale Bianco \& Banarescu, 1982 from the Kor River Basin, southwestern Iran. Iranian Journal of Ichthyology, 1(3), 214-217.

Soylu, E., Uzmanoğlu, S., Çolak, S.Ö., \& Soylu, M.P. (2017). Community Structure of the Parasites of the Endemic Chocolate Chub Squalius carinus Özuluğ \& Freyhof, 2011 (Cyprinidae) from Işıklı Lake, Çivril, Turkey. Acta Zoologica Bulgarica, 69(3), 405-409.

Stavrescu-Bedivan, M.M., Popa, O., Aioanei, F., \& Popa, L. (2011) Infestation of the pumpkinseed Lepomis gibbosus (Teleostei: Cyprinidae) by the copepod Lernaea cyprinacea (Crustacea)-some ecological aspects. Travaux du Muséum National d'Histoire Naturelle" Grigore Antipa" 54(1), 63-68. 
Unal, M.C., Innal, D., Civanova, K., Stavrescu-Bedivan, M.M., Koubkova,

B., Ozmen, O., \& Gelnar, M. (2017). Identification of two gill parasites Lamproglena compacta (Copepoda: Lernaeidae) and Paradiplozoon bliccae (Monogenea: Diplozoidae) from endemic Aegean chub (Squalius fellowesii), Bulletin of The European Association of Fish Pathologists, 37(4), 135-147. 